DOI 10.7764/rcia.v45i3.1762

RESEARCH PAPER

\title{
Lupin and pea extrusion decreases the ruminal degradability and improves the true ileal digestibility of crude protein
}

\author{
Claudia Barchiesi ${ }^{1}$, Pamela Williams ${ }^{2}$, and Alejandro Velásquez ${ }^{3}$ \\ ${ }^{1}$ Universidad de La Frontera, Facultad de Ciencias Agropecuarias y Forestales - PO Box 54 D - Temuco - Chile. \\ ${ }^{2}$ Universidad de Concepción, Facultad de Agronomía - PO Box 537 - Chillán - Chile. \\ ${ }^{3}$ Universidad Católica de Temuco, Departamento de Ciencias Agropecuarias y Acuícolas, Núcleo de \\ Investigación en Producción Alimentaria. Manuel Montt 56, Temuco, Chile.
}

\begin{abstract}
C. Barchiesi, P. Williams, and A. Velásquez. 2018. Extrusion of lupin and pea decrease the ruminal degradability improving true ileal digestibility of crude protein. Cienc. Inv. Agr. 45(3): 231-239. The aim of this work was to evaluate the effect of the extrusion of dehulled lupins (Lupinus albus L.) and peas (Pisum sativum L.) on the ruminal degradability and intestinal digestibility of their protein contents. Ruminal degradability was evaluated in situ in the rumens of two fistulated cows. The true ileal crude protein (CP) digestibility was evaluated via a bioassay with Sprague Dawley laboratory rats as the animal model. Extrusion caused soluble fraction decreases in both feeds $(\mathrm{P}<0.05)$, with a $29 \%$ decrease in the extruded dehulled lupins (EDL) and a $59 \%$ decrease in the extruded peas (EP). The degradable fraction (B) in EP increased by $19 \%$ compared to that in raw peas (RP) $(\mathrm{P}<0.05)$, and there was no effect of extrusion on the degradable fraction in lupins $(\mathrm{P}>0.05)$. Extrusion decreased the effective degradability (ED) of lupins by $12 \%(\mathrm{P}<0.05)$. Moreover, in EP, extrusion presented no effect on the $\mathrm{ED}(\mathrm{P}>0.05)$. The extrusion process had a greater impact on the reduction of the effective degradability in lupins than it did in peas. Nevertheless, extrusion increased the true ileal CP digestibility of the ruminal postfermentation residues in both feeds.
\end{abstract}

Keywords: Digestion, extrusion, legume grains, rumen, rumen undegradable protein.

\section{Introduction}

Among the protein fractions that make up metabolizable protein, microbial protein usually does not satisfy all the requirements of dairy cows. Consequently, diets must be formulated to contribute rumen undegradable protein (RUP) to increase the intestinal availability of protein.
Received Mar 29, 2017. Accepted Aug 23, 2018. Corresponding author: claudia.barchiesi@ufrontera.cl
The flow of undegraded and total feed protein towards the small intestine can be increased if the ruminal degradation of dietary protein is reduced (Jolazadeh et al., 2015; Ouellet and Chiquette, 2016). Protein feeds of plant origin, such as soybean meal, lupins, rapeseed meal and peas, are characterized as having high ruminal degradability (Boguhn et al., 2008).

To increase the contribution of metabolizable protein, one alternative is to use feed protein that is artificially protected from ruminal degrada- 
tion by processing methods to contribute higher amounts of undegradable protein. Among these processing methods, extrusion is an attractive approach because it promotes starch gelatinization and causes partial denaturing of proteins, which decreases the ruminal degradability of feeds rich in crude protein (CP) (Barchiesi and Anrique, 2011).

Bioassays enable the evaluation of the true ileal digestibility of CP in feeds. Specifically, the rat model is considered suitable for nutrition research because results can be quickly obtained, and it has proven to be useful in assessing feeds for other species (Jorgensen and Lindberg, 2005). Some studies employed pigs (Loveday et al., 2005), rats (Chaudhry and Webster, 1993) and roosters (Boucher et al., 2009). Bioassays with rats have been used to estimate the digestibility of amino acids in the terminal ileum (Rutherfurd et al., 2007). Ileal digestibility is a more accurate measure than fecal digestibility because, first, the feed residues are mixed with microorganisms from the gut in fecal measurements and,second, AA do not appear in the fecal sample, as these are used in significant quantities by the microorganism colonies in the large intestine (Moughan, 2003). The aim of this study was to evaluate the effect of protein extrusion on the ruminal degradability and true intestinal digestibility of protein feeds.

\section{Materials and Methods}

\section{Animals and feed}

This study was carried out on an experimental farm in Temuco, Chile ( $38^{\circ} 50^{\prime} \mathrm{S}, 72^{\circ} 41^{\prime} \mathrm{W}$ ). Two Chilean Friesian dairy cows, which were managed on a pasture-based system and fitted with rumen cannula, were used. The cows received 4 $\mathrm{kg} \mathrm{DM}$ day $^{-1}$ of a commercial concentrate $(160 \mathrm{~g}$ $\mathrm{CP} \mathrm{kg}^{-1} \mathrm{DM}$ and 2.9 Mcal ME kg-1 DM at 06:00 and 16:30) and grazed on pasture that consisted predominantly of Lolium perenne L. and Bromus sp. Four feeds were evaluated: dehulled lupin
(DL), dehulled lupin extruded at $140{ }^{\circ} \mathrm{C} / 20 \%$ moisture (EDL), raw peas (RP) and peas extruded at $140{ }^{\circ} \mathrm{C} / 20 \%$ moisture (EP). Before extrusion, the feeds were ground in a mill to pass through a $3 \mathrm{~mm}$ mesh (CYCLOTEC 1093 Sample Mill, Tecator, Denmark). The extrusion experiments were performed using a laboratory single-screw extruder Haake PolyDrive 0 - 120 Nm (Thermo Electron, Karlsruhe GmbH, Germany) with a 25:1 barrel length to diameter ratio, an internal barrel diameter of $19 \mathrm{~mm}$, a 3:1 screw compression ratio and a die nozzle with a $3 \mathrm{~mm}$ diameter. The extruder was mechanically fed at a rate of $3.6 \mathrm{~kg}$ $\mathrm{h}^{-1}$. The extrusion conditions were established at a die temperature of $140{ }^{\circ} \mathrm{C}$ and a screw speed of $80 \mathrm{rpm}$. All animal procedures were approved by the Ethical Committee of the Universidad de La Frontera.

\section{In situ rumen degradability}

In this stage, the in situ degradability of the following feeds was assessed: DL, EDL, RP and EP. Samples of approximately $2.5 \mathrm{~g}$ DM were placed into polyester bags $(5 \times 11 \mathrm{~cm}$; pore size of 40-60 $\mu \mathrm{m}$; Ankom, Turk Hill, NY, USA). The feeds were evaluated in two incubation periods, in which the bags were placed in the rumen of the two cannulated cows at incubation times of 2, 4, 8, 12, 24 and $48 \mathrm{~h}$, with duplicate bags of each sample at each time. The samples were introduced in inverse order to the incubation period to be removed at the same time. Prior to ruminal incubation, the bags were placed in porous laundry bags of $20 \times 30 \mathrm{~cm}$ and soaked in tepid water $\left(30^{\circ} \mathrm{C}\right)$ for $20 \mathrm{~min}$. Once collected from the rumen, the bags were washed with running water and stored at $-20^{\circ} \mathrm{C}$ for at least $24 \mathrm{~h}$. Prior to the laboratory analyses, the bags were thawed and washed in a semiautomatic machine with cold water for $10 \mathrm{~min}$ and then dried at $60^{\circ} \mathrm{C}$ in a forced air oven for $48 \mathrm{~h}$. For soluble nitrogen $(\mathrm{N})$ determination (time 0 ), additional feed samples were soaked in warm water $\left(40^{\circ} \mathrm{C}\right)$ for $2 \mathrm{~h}$ and then dried at $60{ }^{\circ} \mathrm{C}$ for $48 \mathrm{~h}$. Soluble $\mathrm{N}$ was the difference between 
the initial total $\mathrm{N}$ and the remaining $\mathrm{N}$ in the sample (Aufrère et al., 2001).

\section{Bioassay}

To obtain enough RUP residue to conduct the ileal digestibility bioassay, the sample bags were incubated in the rumen of two lactating Chilean Friesian dairy cattle fitted with ruminal fistulas. The cannulas were installed three months prior to the assay. The cows grazed on pasture that consisted predominantly of Lolium perenne L. and Bromus spp. and received $4 \mathrm{~kg} \mathrm{~d}^{-1}$ of a commercial concentrate twice a day (at 06:00 and 16:30). Approximately $20 \mathrm{~g}$ of ground feed was placed in $10 \times 20 \mathrm{~cm}$ polyester bags and suspended in the rumen for $16 \mathrm{~h}$, allowing for 15-20 bags per cow at a time (Chaudhry and Webster, 1993). This process was repeated over several days to obtain a sufficient amount of RUP residue to carry out the intestinal digestibility bioassay. After ruminal incubation, the bags were washed with cold tap water and stored at $-20^{\circ} \mathrm{C}$ for at least $24 \mathrm{~h}$ and then defrosted and washed with cold water in a semiautomatic washing machine for $10 \mathrm{~min}$. The bags were dried in an oven at $60^{\circ} \mathrm{C}$ for $48 \mathrm{~h}$ and weighed. The residues of approximately $80 \mathrm{bags}$ of each feed were mixed and stored until required.

The postruminal fermentation residues of DL, EDL, $\mathrm{RP}$ and EP were used as the exclusive sources of $\mathrm{CP}$ in the rat diets. The diets (Table 2) were for- mulated according to the nutritional requirements of laboratory rats (NRC, 1995) to be isoproteic. To determine the endogenous $\mathrm{N}$ fraction, a diet was prepared with enzyme-hydrolyzed casein (EHC, Sigma P6838, size $<3,000$ Da) instead of the residue. To calculate the flow of digesta, chromic oxide was incorporated into the diets as an indigestible marker. Growing male SpragueDawley rats were placed into six groups (eight rats per group), and the groups were randomly assigned to each diet. The average initial weight of the rats was $246 \mathrm{~g}( \pm 37)$.

\section{Experimental protocol and the collection of ileal digesta}

The rats were placed in individual cages with a metal grid floor to minimize coprophagia. The rats had permanent free access to water. The temperature of the room was kept at $21^{\circ} \mathrm{C}$, and lighting was maintained in $12 \mathrm{~h}$ cycles of light/darkness. The animals had a period of five days to adapt to the environment and feeding regime. During this time, the rats ate a commercial laboratory rat diet. The animals had access to the diet for 10 min every hour for $8 \mathrm{~h} \mathrm{~d}^{-1}$ (starting at 08:00 and ending at 15:00). The amount of each diet offered was $16 \mathrm{~g} \mathrm{DM} \mathrm{d}^{-1}(5 \%$ more than average intake for growing rats and adult rats at maintenance). After the adaptation phase, the experimental diets were fed for five days, which was the period needed for residue availability. The leftovers were weighed

Table 2. Composition of the experimental diets (\% DM).

\begin{tabular}{lccccc}
\hline Ingredients & $\begin{array}{c}\text { Diet 1 } \\
\text { DL }\end{array}$ & $\begin{array}{c}\text { Diet 2 } \\
\text { EDL }\end{array}$ & $\begin{array}{c}\text { Diet 3 } \\
\text { RP }\end{array}$ & $\begin{array}{c}\text { Diet 4 } \\
\text { EP }\end{array}$ & $\begin{array}{c}\text { Diet 5 } \\
\text { EHC }^{\dagger}\end{array}$ \\
\hline EHC (Sigma P6838) & -- & - & - & - & 20.0 \\
Ruminal residue & 21.4 & 17.3 & 17.2 & 12.2 & - \\
Sucrose & 53.8 & 55.0 & 55.0 & 62.8 & 50.1 \\
Corn starch & 15.0 & 17.9 & 18.0 & 15.2 & 15.0 \\
Cellulose & - & - & - & - & 5.0 \\
Rapeseed oil & 5.0 & 5.0 & 5.0 & 5.0 & 5.0 \\
Vitamins-minerals & 4.6 & 4.6 & 4.6 & 4.6 & 4.6 \\
Chrome oxide & 0.3 & 0.3 & 0.3 & 0.2 & 0.3 \\
CP, \% of diet & 9.7 & 9.8 & 9.3 & 9.4 & 8.9 \\
\hline
\end{tabular}

$\mathrm{DL}=$ dehulled lupin; $\mathrm{EDL}=$ extruded dehulled lupin, $140{ }^{\circ} \mathrm{C} / 20 \%$ moisture; $\mathrm{RP}=$ raw peas; $\mathrm{EP}=$ extruded peas, $140{ }^{\circ} \mathrm{C} / 20 \%$ moisture. ${ }^{\dagger} \mathrm{EHC}=$ enzyme hydrolyzed casein. 
after each feeding period to calculate individual intake. On the last day, the rats were asphyxiated with $\mathrm{CO}_{2}$ and decapitated. The last $20 \mathrm{~cm}$ of the terminal ileum were dissected, and the digesta was gently expelled with a wash bottle by injecting deionized distilled water at the section point of the ileum(Hodgkinson et al., 2003). The samples were immediately frozen $\left(-20^{\circ} \mathrm{C}\right)$, freeze dried and stored $\left(-20^{\circ} \mathrm{C}\right)$ until chemical analysis.

\section{Chemical analysis}

In the feed samples, ruminal residues and ileal digesta, dry matter (DM) (AOAC, 1996, method 930.15) CP was analyzed using a LECO FP 528 analyzer based on the DUMAS method (AOAC, 1996, method 993.13). Ether extract (EE) (AOAC, 1996, method 920.39) and neutral detergent fiber (aNDFom) (Mertens, 2002.) were also analyzed. The chrome oxide $\left(\mathrm{Cr}_{2} \mathrm{O}_{3}\right)$ concentration in the diets and in the ileal digesta were determined using an atomic absorption spectrometer (Fenton and Fenton, 1979). Four samples of the ruminal residues and rat diets were analyzed for $\mathrm{CP}$.

The digesta obtained from the rats fed the EHC diet was centrifuged at $7000 \mathrm{x}$ g for $10 \mathrm{~min}$ at $4{ }^{\circ} \mathrm{C}$. The supernatant was decanted into Centriprep-3 ultrafiltration tubes (Amicon, Beverly, MA) (3000 $\mathrm{Da}$ ), and a small volume of water was added to the precipitate. The tube containing the precipitate was shaken and centrifuged $\left(3000 \mathrm{x} \mathrm{g}\right.$ for 10 min at $4{ }^{\circ} \mathrm{C}$ ), and the supernatant was added to a Centriprep-3 tube. The precipitate was stored at $-20^{\circ} \mathrm{C}$, and the supernatant from the Centriprep tube was ultrafiltered according to the manufacturer's instructions. The fraction with the highest molecular weight was added to the precipitate, which was freeze dried until later analysis (Hendriks et al., 2002).

\section{Statistical analysis}

For the evaluation of ruminal degradability, an exponential model (Orskov and McDonald, 1979) was used to measure the disappearance of DM and $\mathrm{CP}$ from the residues and to estimate the kinetic constants and potential degradation (PD). The exponential model was as follows:

$P D=A+B\left(1-e^{-k t}\right)$

where $\mathrm{A}$ is the soluble fraction $\left(\mathrm{g} \mathrm{kg}^{-1}\right.$, washed at $\mathrm{t}=0$, resulting from the incubation of $0 \mathrm{~h}$ bags and fixed into the model); $\mathrm{B}$ is the potentially degradable nonsoluble fraction $\left(\mathrm{g} \mathrm{kg}^{-1}\right) ; k$ is a constant that represents the fractional degradation rate $\left(\mathrm{h}^{-1}\right)$; and $t$ is the time (h). The estimation parameters of $\mathrm{A}, \mathrm{B}$, and $k$ were obtained by adjusting the model using the nonlinear regression procedure NLIN. The effective degradability (ED, $\mathrm{g} \mathrm{kg}^{-1}$ ) of the DM and $\mathrm{CP}$ was determined using a solid passage rate in the rumen of $0.06 \mathrm{~h}^{-1}$ Prior to ANOVA, the normality of the data was verified using the Shapiro-Wilk procedure $(\mathrm{P}>0.05)$. Levene's statistic was used to test for homogeneity of variance $(\mathrm{P}>0.05)$. A factorial ANOVA was carried out: $\left(\mathrm{Y}=\mu+\right.$ feed $_{\mathrm{i}}+$ extrusion $_{\mathrm{j}}+$ (feed $\mathrm{x}$ extrusion) $\left.{ }_{\mathrm{ij}}+\mathrm{e}\left(\mathrm{ijk}_{\mathrm{j} k}\right)\right)$. The parameters of degradability were analyzed using Fisher's test, considering $\mathrm{P}<0.05$ :

$\mathrm{ED}=\mathrm{A}+\mathrm{B}\left(k /\left(k+k_{\mathrm{p}}\right)\right)$

The total and endogenous ileal flow (EHC diet) of the $\mathrm{N}$ in the terminal ileum was calculated using the following equation:

\section{Flow of ileal $\mathrm{N}(\mu \mathrm{g} / \mathrm{gDM})=\underline{\mathrm{N} \text { ileal digesta } x \text { Cr in feed }}$ $\mathrm{Cr}$ in ileal digesta}

The true ileal digestibility (\%) of $\mathrm{N}$ was calculated as follows:

True $\mathrm{N}$ digestibility $=$ Dietary $\mathrm{N}-$ (flow of ileal $\mathrm{N}$ - flow of endogenous N) $\times 100$

Dietary N

The EHC diet was used to determine the endogenous flow of $\mathrm{N}$ in the rats and was therefore not included in the statistical analyses. Differences were considered significant at $\mathrm{P}<0.05$. If significance 
was found, the measurements were compared using Fisher's test. The statistical analyses were performed using the GLM procedure of the statistical program JMP version 8 (SAS Institute, 2009).

\section{Results and Discussion}

\section{Chemical composition}

Table 1 presents the chemical composition of the feeds. The values obtained are consistent for both peas and dehulled lupins, with the results reported by Anrique et al. (2014). The decrease in the NDF found in the lupins and peas as a result of extrusion could be due to a partial depolymerization of the polysaccharides in the cell wall, which would render them more soluble in the acid and alkali solutions used during the analysis (Solanas et al., 2005). This decrease in NDF has also been observed in lupins, as well as in mixtures of peas with extruded rapeseed and peas with extruded corn and rapeseed meal (Barchiesi and Anrique, 2011).

\section{Crude protein degradation kinetics}

A reduction in the soluble fraction " $A$ " was observed in the extruded treatments $(\mathrm{P}<0.05)$, causing a decrease of $29 \%$ in EDL and $59 \%$ in EP. EP showed the lowest "A" value (139 g $\mathrm{kg}^{-1}$ ) (Table 3). This result could be due to the

Table 1. Chemical composition of the feeds $\left(\mathrm{g} \mathrm{kg}^{-1} \mathrm{DM}\right)$.

\begin{tabular}{lcccc}
\hline & DL & EDL & RP & EP \\
\hline Dry matter & 914 & 934 & 901 & 929 \\
Crude protein & 449 & 463 & 229 & 226 \\
Ether extract & 84 & 56 & 80 & 80 \\
Neutral detergent fiber & 84 & 62 & 326 & 309
\end{tabular}

$\mathrm{DL}=$ dehulled lupin; $\mathrm{EDL}=$ extruded dehulled lupin, $140{ }^{\circ} \mathrm{C} / 20$ $\%$ moisture; $\mathrm{RP}=$ raw peas; $\mathrm{EP}=$ extruded peas, $140{ }^{\circ} \mathrm{C} / 20 \%$ moisture. nonstructural fraction of the carbohydrate content in peas, which is higher than that in lupins. Nonstructural carbohydrates are prone to react with protein, diminishing its solubility at the ruminal level, which is in accordance with the results of Solanas et al. (2008). Starch gelatinization promotes a decrease in protein solubility (Solanas et al., 2008) caused by a partial Maillard reaction that participates in the denaturation of proteins during extrusion. Therefore, the use of higher temperatures during extrusion $\left(>140{ }^{\circ} \mathrm{C}\right.$ according to this study), mainly in starch-rich substrates, can affect the bioavailability of the amino acids that make up these proteins.

No differences were observed in the " $\mathrm{B}$ " fraction among the lupins studied $(\mathrm{P}>0.05)$; the results are consistent with those reported by Solanas et al. (2008). Different lupin studies have shown increases of greater magnitudes in the potentially degradable fraction as a result of extrusion, where the potentially degradable fraction has been increased by $52 \%$ (Rémond et al., 2003). However, the magnitude of the increase in "B" in this investigation was much lower (4 $\%$ ) than those reported by these authors, which can be attributed to the use of dehulled lupin. Lampart-Szczapa et al., 2006 made a comparison between normal and dehulled lupin seed and found a lower moisture absorption capacity in the dehulled lupin, which may negatively affect the Maillard reaction; that situation is reflected in this study. In the " $\mathrm{B}$ " fraction of peas, the

Table 3. Parameters of the ruminal degradation of the crude protein in the dehulled lupin, extruded dehulled lupin, peas and extruded peas evaluated in situ.

\begin{tabular}{lccccc}
\hline & DL & EDL & RP & EP & SEM \\
\hline $\mathrm{A}$ & $342 \mathrm{a}$ & $244 \mathrm{~b}$ & $344 \mathrm{a}$ & $139 \mathrm{c}$ & 7.1 \\
$\mathrm{~B}$ & $655 \mathrm{~b}$ & $683 \mathrm{~b}$ & $618 \mathrm{~b}$ & $760 \mathrm{a}$ & 12.3 \\
$\mathrm{k}$ & $0.17 \mathrm{~b}$ & $0.15 \mathrm{~b}$ & $0.15 \mathrm{~b}$ & $0.39 \mathrm{a}$ & 0.051 \\
$\mathrm{ED}$ & $823 \mathrm{a}$ & $727 \mathrm{~b}$ & $785 \mathrm{ab}$ & $797 \mathrm{a}$ & 15.3 \\
\hline
\end{tabular}

A: soluble fraction $\left(\mathrm{g} \mathrm{kg}^{-1}\right)$; B: insoluble potentially degradable fraction $\left(\mathrm{g} \mathrm{kg}^{-1}\right)$; $\mathrm{k}$ : rate of degradation of $\mathrm{B}\left(\mathrm{h}^{-1}\right)$; ED: effective degradability assuming $\mathrm{k}_{\mathrm{p}}=0.06 \mathrm{~h}^{-1}\left(\mathrm{~g} \mathrm{~kg}^{-1}\right)$. Different letters in each row correspond to significant differences using Fisher's LSD test. $\mathrm{SEM}=$ standard error of the means; $\mathrm{DL}=$ dehulled lupin; $\mathrm{EDL}=$ extruded dehulled lupin, $140{ }^{\circ} \mathrm{C} / 20 \%$ moisture; $\mathrm{RP}=$ raw peas; $\mathrm{EP}=$ extruded peas, $140{ }^{\circ} \mathrm{C} / 20 \%$ moisture. 
increase observed as a result of extrusion was 19 $\%$, which is less than half of $42 \%$, the increase observed in other studies (Solanas et al., 2005). In the latter work, extrusion was performed at $185^{\circ} \mathrm{C}$, which is a high temperature that had a greater effect on protein protection and was evaluated in vivo in ruminants. Since the carbohydrates in raw peas react with the protein in grains during extrusion, an increase in the degradable fraction is generated, reducing the soluble fraction of the feed.

In lupins, the effective degradability (ED) decreased by $12 \%$ as a result of extrusion $(\mathrm{P}<0.05)$. Despite the decrease in the " $\mathrm{A}$ " fraction in the extruded peas, the ED of the peas did not present any differences as a result of extrusion $(\mathrm{P}>0.05)$. Extrusion reduced the solubility and the fractional degradation rate in the lupin, which was also observed by Rémond et al. (2003) and Ramos-Morales et al. (2010). In this study, the ED obtained in lupins was lower than that in the abovementioned works, which may be attributed to the use of dehulled lupin instead of whole grain. The ED of EDL was similar to that observed in Rémond et al. (2003) (extrusion at $162{ }^{\circ} \mathrm{C}$ ) and Solanas et al. (2005) (extrusion at $140{ }^{\circ} \mathrm{C}$ ), who worked with lupins with hulls. However, this finding differs from the results presented by Barchiesi and Anrique (2011) (extrusion at $130^{\circ} \mathrm{C}$ ), where an ED of $788 \mathrm{~g} \mathrm{~kg}^{-1}$ with a rate of $0.05 \mathrm{~h}^{-1}$ was obtained, which may be attributable to the lower temperature used in the extrusion cooking process in the latter study, suggesting that lupins might need a temperature over $140^{\circ} \mathrm{C}$ and a higher percentage of moisture to cause denaturing of the $\mathrm{CP}$. The increase in the degradation rate of the degradable fraction $(k)$ in the ED prevented a greater extrusion effect in peas.

\section{Crude protein intestinal digestibility}

The rats were in good condition during the assay. There was no evidence of coprophagia in the animals. Table 4 displays the intake values of DM and CP; the initial and final weights of the rats in each treatment; and the coefficients of the true intestinal digestibility of the CP. No interactions were found between feed and extrusion. The DM intake ranged between 13.7 and $15.1 \mathrm{~g} \mathrm{~d}^{-1}$, which is consistent with the requirements indicated by the NRC for growing rats and adult rats at maintenance. The CP intake varied between 1.2 and $1.4 \mathrm{~g} \mathrm{~d}^{-1}$. In all treatments, the rats exhibited a decrease in live weight, which ranged between $3 \%$ and $6 \%(\mathrm{P}<0.05)$. The greatest decreases in weight were observed in the treatments with peas. These decreases could be due to the rats consuming less protein. Although the DM intake was set according to the maintenance requirements presented in the NRC (1995), the available CP was not enough to meet the $\mathrm{CP}$ maintenance requirements for the Sprague-Dawley rats in one of the diets. The available CP was in a range between $7 \%$ and $12 \%$ of the diet for maximum growth. Moreover, the reduction in live weight may also be attributed to a dietary energy level lower than the requirements; given that the diets were formulated from the ruminal fermentation residuals to be isoproteic, some deficiencies in the energy contribution of each treatment may have occurred, thus making it more difficult to estimate the energy contribution for the animals on each diet. It is important to note that the higher true ileal protein digestibility obtained in EP could be a nutritional strategy of the rat to improve the efficiency of the use of dietary protein to compensate for the lower crude protein consumption in those animals.

True ileal digestibility was higher in the diet with EDL residues and exceeded the digestibility obtained with DL by $11 \%(\mathrm{P}<0.05)$. Additionally, EP presented an $8 \%$ greater protein digestibility than $\mathrm{RP}(\mathrm{P}<0.05)$. The true ileal digestibility of the extruded feeds $(\mathrm{P}<0.05)$ was greater than that of the nonextruded feeds (differences of $8 \%$ for peas and $11 \%$ for lupins), with the greatest impact observed on the lupins. The highest true ileal digestibility observed in EDL is consistent with that presented in Table 2, considering the low ruminal $\mathrm{CP}$ degradability 
Table 4. Dry matter and crude protein intake, DM metabolic intake, average metabolic weight of rats, and true ileal digestibility of the protein (mean \pm standard error).

\begin{tabular}{lcccccc}
\hline & Diet & Diet & Diet & Diet & \multirow{2}{*}{ SEM } & P \\
& DL & EDL & RP & EP & & \\
\hline DM intake, g & $15.14 \mathrm{a}$ & $14.53 \mathrm{a}$ & $14.89 \mathrm{~b}$ & $13.7 \mathrm{ab}$ & 0.22 & $*$ \\
CP intake, $\mathrm{g}$ & $1.40 \mathrm{a}$ & $1.37 \mathrm{a}$ & $1.27 \mathrm{~b}$ & $1.16 \mathrm{c}$ & 0.04 & $*$ \\
DM metabolic intake, g & $24.07 \mathrm{~b}$ & $27.19 \mathrm{a}$ & $22.79 \mathrm{~b}$ & $27.26 \mathrm{a}$ & 0.55 & $*$ \\
Average initial metabolic weight & $66.5 \mathrm{~b}$ & $56.5 \mathrm{a}$ & $69.7 \mathrm{~b}$ & $56.0 \mathrm{a}$ & 1.28 & $*$ \\
Average final metabolic weight & $64.8 \mathrm{~b}$ & $54.4 \mathrm{a}$ & $66.6 \mathrm{~b}$ & $53.6 \mathrm{a}$ & 1.30 & $*$ \\
True protein ileal digestibility, $\mathrm{g} \mathrm{kg}^{-1} \mathrm{DM}$ & $793 \mathrm{~d}$ & $889 \mathrm{~b}$ & $851 \mathrm{c}$ & $927 \mathrm{a}$ & 1.88 & $*$ \\
\hline
\end{tabular}

Letters in the same row indicate statistically significant differences using Fisher's test. ${ }^{*} P<0.05$; ns $=$ not significant. $\mathrm{SEM}=$ standard error of the means; $\mathrm{DL}=$ dehulled lupin; $\mathrm{EDL}=$ extruded dehulled lupin, $140{ }^{\circ} \mathrm{C} / 20$ $\%$ moisture; $\mathrm{RP}=$ raw peas; $\mathrm{EP}=$ extruded peas, $140{ }^{\circ} \mathrm{C} / 20 \%$ moisture

obtained in EDL. The results of this study also differ from the results obtained by Solanas et al. (2005), who obtained apparent intestinal digestibility increases of $45 \%$ in peas and 18 $\%$ in lupins. These differences were due to the methodologies employed in most ruminant research using duodenal cannulas to introduce bags with digested feed residues into the rumen, and the bags are subsequently collected in the feces. When fecal samples are used to determine digestibility, it must be considered that the presence of microorganisms that metabolize several nitrogen compounds in the large intestine cause a change in the AA profile of the digesta. In addition to the possible bacterial contamination of the residues, bacterial contamination occurs in the rumen. True ileal digestibility is considered a more precise measurement for determining the AA absorbed from the intestine, and it enables a better representation of protein quality than does apparent digestibility (Hodgkinson, 2006). This aspect was considered in this study when correcting the digesta protein for endogenous protein losses. Another reason for the differences between this study and others that obtained a greater digestibility increase of extruded peas over extruded lupins may be that, in this study, dehulled lupin was assessed unlike the other studies that used lupins with the hulls. During extrusion, the fiber in the pod promotes moisture retention and completion of the Maillard reaction (Lampart-Szczapa et al., 2006). The different results reported among studies may be due to different processing conditions (temperature and moisture), the type and composition of the concentrate mixture, differences in the sample preparation (particle size) and the legume species.

The extruded feeds obtained a higher coefficient of true ileal digestibility than the nonextruded feeds. The true ileal protein digestibility was greater in the diet with residues from extruded peas than from extruded lupins. Extrusion modified the ruminal degradation parameters of feeds and made it possible to increase the true ileal digestibility of the feeds evaluated.

\section{Acknowledgements}

This research was made possible due to funding from Project DI09-0004 of the Research Directorate of the Universidad de La Frontera (Temuco, Chile). 


\title{
Resumen
}

\begin{abstract}
C. Barchiesi, P. Williams, y A. Velásquez. 2018. La extrusión en lupino y arveja disminuye la degradabilidad ruminal, mejorando la digestibilidad ileal verdadera de la proteína cruda. Cienc. Inv. Agr. 45(3): 231-239. Se evaluó el efecto de la extrusión en la degradabilidad ruminal y la digestibilidad intestinal de la proteína del lupino descascarado (Lupinus albus L.) y de arveja (Pisum sativum L.). La degradabilidad ruminal se evaluó in situ en el rumen de dos vacas fistuladas. La digestibilidad ileal verdadera de la proteína cruda (PC) se evaluó mediante un bioensayo con ratas de laboratorio Sprague Dowley como modelo animal. Los alimentos extruidos, en relación a los alimentos originales, mostraron una disminución de la fracción soluble $(\mathrm{P}<0.05)$ del $29 \%$ en el lupino descascarado extruido (LDE) y el $59 \%$ en arveja extruida (AE). La fracción degradable (B) sólo aumentó en AE en 19\% en comparación con la arveja cruda (AC) $(\mathrm{P}<0.05)$, sin embargo, en el lupino no hubo efectos sobre la extrusión en esta fracción $(\mathrm{P}>0.05)$. La degradabilidad efectiva (DE) en el lupino disminuyó en un $12 \%$ mediante extrusión $(\mathrm{P}<0.05)$. Por otra parte, en $\mathrm{AE}$ la $\mathrm{DE}$ no presentó ningún efecto como resultado de la extrusión $(\mathrm{P}>0.05)$. El proceso de extrusión tuvo un mayor impacto en la reducción de la degradabilidad efectiva en el lupino que en la arveja. Sin embargo, la extrusión aumentó la digestibilidad ileal verdadera de la PC de los residuos post-fermentación ruminal en ambos alimentos.
\end{abstract}

Palabras clave: Digestión, extrusión, granos de leguminosas, proteínas no degradables en el rumen, rumen.

\section{References}

Anrique, R., X. Molina, M. Alfaro, and R. Saldaña. 2014. Composición de alimentos para el ganado bovino. 4ed. Universidad Austral de Chile, Instituto de Investigaciones Agropecuarias, Consorcio Lechero. Valdivia, Chile.

Association of Official Analytical Chemists [AOAC]. 1996. Official Methods of Analysis. 16ed. AOAC, Gaithersburg, MD, USA.

Aufrère, J., D. Graviou, J. Melcion, and C. Demarquilly. 2001. Degradation in the rumen of lupin (Lupinus albus L.) and pea (Pisum sativum L.) seed proteins: Effects of heat treatment. Anim. Feed Sci. Technol. 92:215-236.

Barchiesi, C., and R. Anrique. 2011. Ruminal degradability of dry matter and crude protein from moist dehulled lupin and extruded rapeseed meal. Chilean J. Agric. Res. 71:430-436.

Boguhn, J., H. Kluth, M. Bulang, T. Engelhard, J. Spilke, and M. Rodehutscord. 2008. Effects of using thermally treated lupins instead of soy- bean meal and rapeseed meal in total mixed rations on in vitro microbial yield and performance of dairy cows. J. Anim. Physiol. Anim. Nutr. 92:694-704.

Boucher, S., S. Calsamiglia, C. Parsons, H. Stein, M. Stern, P. Erickson, P. Utterback, and C. Schwab. 2009. Intestinal digestibility of amino acids in rumen undegradable protein estimated using a precision-fed cecectomized rooster bioassay: I. Soybean meal and SoyPlus. J. Dairy Sci. 92:4489-4498.

Chaudhry, A., and A. Webster. 1993. The true digestibility and biological value for rats of undegraded dietary nitrogen in feeds for ruminant. Anim. Feed Sci. Technol. 42:209-221.

Fenton, T., and M. Fenton. 1979. An improved procedure for the determination of chromic oxide in feed and feces. Can. J. Anim. Sci. 59:631-634.

Hendriks, W., K. Sritharan, and S. Hodgkinson. 2002. Comparison of the endogenous ileal and faecal amino acid excretion in the dog (Canis familiaris) and the rat (Rattus rattus) determined under 
protein-free feeding and peptide alimentation. J. Anim. Physiol. Anim. Nutr. 86:333-341.

Hodgkinson, S. 2006. Evaluation of the quality of protein sources for inclusion in diets for monogastric animals. Cien. Inv. Agr. 33:83-90.

Hodgkinson, S., W. Souffrant, and P. Moughan. 2003. Comparison of the enzyme-hydrolyzed casein, guanidination, and isotope dilution methods for determining ileal endogenous protein flow in the growing rat and pig. J. Anim. Science 81:2525-2534.

Jolazadeh, A., M. Dehghan-banadaky, and K. Rezayazdi. 2015. Effects of soybean meal treated with tannins extracted from pistachio hulls on performance, ruminal fermentation, blood metabolites and nutrient digestion of Holstein bulls. Anim. Feed Sci. Technol. 203:33-40.

Jorgensen, H., and J. Lindberg. 2005. Prediction of energy and protein digestibility in pig feeds using growing rats as a model. Anim. Feed Sci. Technol. 127:55-71.

Lampart-Szczapa, E., P. Konieczny, M. NogalaKalucka, S. Walczak, I. Kossowska, and M. Malinowska. 2006. Some functional properties of lupin proteins modified by lactic fermentation and extrusion. Food Chem. 96:290-296.

Loveday, D., P. Thacker, D. Wilson, and J. McKinnon. 2005. Validation of the cannulated pig model for determining intestinal nutrient disappearance in cattle. Can. J. Anim. Sci. 85:85-91.

Mertens, D. R. 2002. Gravimetric determination of amylase-treated neutral detergent fiber in feeds with refluxing in beakers or crucibles: Collaborative study. J. AOAC Int. 85:1217-1240.

Moughan, P. 2003. Amino acid availability: aspects of chemical analysis and bioassay methodology. Nutr. Res. Rev. 16:127-141.
NRC, 1995. Nutrient Requirements of Laboratory Animals. National Academy Press Washington, USA.

Orskov, E. and I. McDonald. 1979. The estimation of protein degradability in the rumen from incubation measurements weighted according to rate of passage. J. Agric. Sci. 92:499-502.

Ouellet, D. and J. Chiquette. 2016. Effect of dietary metabolizable protein level and live yeasts on ruminal fermentation and nitrogen utilization in lactating dairy cows on a high red clover silage diet yeast and metabolizable protein supply for cows. Anim. Feed Sci. Technol. 220:73-82.

Ramos-Morales, E., M. Sanz-Sampelayo, and E. Molina-Alcalde. 2010. Nutritive evaluation of legume seeds for ruminant feeding. J. Anim. Physiol. Anim. Nutr. 94:55-64.

Rémond, D., M. LeGuen, and C. Poncet. 2003. Degradation in the rumen and nutritional value of lupin (Lupinus albus L.) seed proteins affect of extrusion. Anim. Feed Sci. Technol. 105:55-70.

Rutherfurd, S., K. Rutherfurd-Markwick, and P. Moughan. 2007. Available (Ileal digestible reactive) lysine in selected pet foods. J. Agric. Food Chem. 55:3517-3522.

SAS Institute Inc. 2009. JMP 8 Design of Experiments, Cary, NC: SAS Institute Inc.

Solanas, E., C. Castrillo, J. Balcells, and J. Guada. 2005. In situ ruminal degradability and intestinal digestion of raw and extruded legume seeds and soya bean meal protein. J. Anim. Physiol. Anim. Nutr. 89:166-171.

Solanas, E.; C. Castrillo, M. Fondevila, Q. Ruiz Narvaez, and J. Guada. 2008. Effects of cereals and/ or protein supplement extrusion on diet utilisation and performance of intesively reared cattle. Livest. Sci. 117:203-214. 